\title{
Cromwell's Message to the Regulars: The Biblical Trilogy of John Bale, 1537*
}

\author{
SEYMOUR BAKER HOUSE
}

\begin{abstract}
A s mother and midwife of the English Reformation, Thomas Cromwell displayed remarkable ingenuity in his use of propaganda between 1535 and 1540. Anticipating the saturation techniques of modern politicians, he initiated a country-wide campaign of preaching and publishing to sway public opinion toward support for the government's emerging policies of reform. In addition to press and pulpit, Cromwell used a company of actors to bring his message of reform to distant parishes throughout the English countryside. This paper will examine one particularly illuminating performance before the Cluniac monks at Thetford in 1537 and argue that in this case, Cromwell's troupe tempered their polemic in response to the recent uprisings in defence of the English monasteries. ${ }^{1}$
\end{abstract}

From 1537 until his execution in 1540, Cromwell supported a troupe of players headed by the notorious "bilious" John Bale, ex-Carmelite and later Anglican bishop of Ossory. This group toured for three years, enacting Bale's protestant drama in town halls, cloisters, and houses throughout England until their patron's own brief candle was snuffed and Bale was forced to flee the realm. Indeed, Cromwell was not alone in employing travelling players during this time: by the late 1530s there were over a dozen such troupes and it is certain that the plays they staged were, in some measure, as reflective of their patron's relation to the quickly changing scenes as Bale's were of his. The association of Cromwell and Bale permits us to investigate the partnership of patron/playwright at a crucial juncture in the history of the English Reformation. In them we can see how a patron of the 'new learning' used a like-minded dramatist to further public policy. ${ }^{2}$

Despite the relative abundance of his polemical prose, only five of Bale's plays have come down to us from among the nearly two dozen he wrote between ca. 1533 and 1538 . All of his dramatic works were largely scriptural and rooted in the vigorously expressed reformed theology for which he was 


\section{4 / Renaissance and Reformation}

famous. In Cromwell's hands, each became potential weapons in a program of religious reform which was promulgated under the guise of a return to the purity of the early Church, free from its medieval accretions-accretions which included not only various sacramental and traditional matters, but also the dramatic aspects of medieval Christianity such as pageants, cycle plays, and processions.

Yet parish drama had become part of the very fabric of English life, and could not be eradicated overnight. Early writers of Protestant plays may even have benefited from the ready acceptance and universal familiarity of the mystery and miracle plays which guaranteed them an audience for the dissemination of their Protestant doctrine. Bale's life of John the Baptist in 14 episodes was clearly an attempt to combat the medieval mystery plays using the very form which would survive, protected by towns or church and craft guilds, in parts of England well into Elizabeth's reign. ${ }^{3}$ Despite the similarity in presentation, differences in theology could not be tolerated and it was not long until legislation began to curtail Protestant interludes.

Because their plays were drawn largely from the Bible, reformers like Bale could present their objections to Catholic praxis while emphasizing their belief that scriptural fidelity-increasingly a literal fidelity - was the only sure guide to theological verity. There is a further and scarcely less significant aspect of this deepening literalism: it supported the conflation of the Divine with the human and permitted a typological view of history in which Henry VIII becomes another King David, in which all human actions are seen in a Biblical context. ${ }^{4}$ Cromwell was not slow to recognise that such a view was ideally suited for polemical purposes.

Bale's work with Cromwell, which coincides with the appearance of a troupe of players under the Lord Privy Seal's protection, began in earnest in January 1537 when, after plucking him from prison in Greenwich, Cromwell set him to work producing plays for the reformation. ${ }^{5}$ Tudor drama has long been known for its political nature, yet most pieces written during this period have resisted precise dating and, by extension, a convincing assignation of auspices. Bale's are an exception, although to date, known performances of the propaganda plays he produced are few. Cromwell's men (led by Bale) appear for the first time on 8 September 1537 at Kings' College, Cambridge. Also in 1537/8 they appeared at Shrewsbury, Leicester, Thetford, New College (Oxford) and Cambridge town hall. In addition to the royal performance in September 1538, Bale was paid by Cromwell for putting on a play before Cranmer in Canterbury during the Christmas season 1538/39. This was most likely a staging of King Johan and proved more provocative than the 
previous performance, They also appeared at Barnstaple in 1538/9, again (perhaps) at Thetford between June 1539 and its suppression in January 1540, and before 29 June 1540 in York, Maldon, and again at Cambridge. ${ }^{6}$ The only known performance of his trilogy, The chefe promyses of god, Johan Baptystes preachynge, and The temptacyon of our lorde, led by Bishop Bale himself in conservative Kilkenny in 1553 to counter the processions acclaiming Mary Tudor as queen, resulted in his immediate exile. Other than on these noteworthy occasions, no other venues for his dramatic works are known. There was a practice for a performance of his Thre Lawes around Christmas $1550 / 1$ near Bale's Hampshire cure of Bishopstoke, but it is uncertain whether a performance ever resulted. ${ }^{7}$

It is clear that Bale's plays were tailored for different occasions, and that his repertoire included many pieces written in response to single issues. Many betray this essentially partisan nature and the specific application for which they were intended through their titles alone: On the king's two marriages, for example, may date from spring, 1534 when preachers were ordered to uphold the king's marriage and certainly could not have been played after May 1536 when proceedings against Anne Boleyn had begun, while On the treasons of Becket suggests the performance on 8 September 1538 when Bale actually performed before the king and court in Canterbury the night after England's most famous shrine had been dismantled there. ${ }^{8}$

There is, however, ample evidence, both internal and otherwise, to suggest that it was his relatively mild trilogy that Bale played when touring those areas of the country most hostile to the 'new learning' as well as to monastic audiences. In particular, it seems to have been staged during the 1537 winter dramas at the Cluniac priory in Thetford, Norfolk and presented in the conservative northern cities of Leicester and Shrewsbury that same year in a deliberate effort to preempt opposition to the anticipated suppression of the greater religious houses and to induce the lay and regular members of the audience to acquiesce in the king's ecclesiastical reforms. While the performance at Leicester town hall is datable only to between Michaelmas 1537 and Michaelmas 1538, at Shrewsbury we have two likely dates to choose from. Bishop Hilsey, ever active in the suppression of the monasteries, preached there for all of Rogation week 1537, and Dr. Legh, also a tireless campaigner for Cromwell, visited the town's regulars around late August 1537 and was feasted in the town hall. Either of these times would have been suitable for the production, before the mayor, aldermen and regulars, of Bale's Biblical trilogy. ${ }^{9}$ 
That Cromwell was facing stiff opposition in his planned reforms needs scant mention. By March 1536, the religious houses in England worth under 200 pounds per annum were dissolved by act of parliament and some surrenders of larger houses had occurred by the end of the year. The Pilgrimage of Grace, involving as it did over 30,000 men-by far the gravest threat to Henry's reign - had specifically taken up the suppression as one of its main points and despite its defeat by December 1536, new risings had followed in the spring of 1537, notably in Somerset, Cornwall, and East Anglia itself. Bale's own parish of Thorndon was particularly sympathetic to the northern men and brought charges against Bale (which led to his arrest) when he chastised them for it. ${ }^{10}$ Rumors of still further risings were rife. After Easter, 1537, it was bruited that Walsingham was up and in Suffolk on May Day an overtly political game was staged in which the duke of Suffolk, one of the main agents of the king's victory over the rebels, was criticized. Cromwell too had become the target of malicious songs and ditties and his resignation had been foremost among the demands of the northern rebels in $1536 .{ }^{11}$ More threateningly, between March and October 1537, risings and rumors of risings had been linked to the threat of further monastic suppressions in both Shrewsbury and Leicester. ${ }^{12}$ Although by mid- 1537 the wholesale suppression of all remaining houses had not yet been ordered, the monastic visitors were making their rounds, visiting both Shrewsbury and Thetford in their turn and the larger monasteries whose heads had been involved in the recent uprisings were dissolved through the attainder of their leaders. ${ }^{13}$ By late autumn, Thetford must have known that its future was in jeopardy - two other Cluniac priories had recently been suppressed, including the premier house at Lewes which surrendered voluntarily to the king in November $1537 .{ }^{14}$

Into this climate of dangerous dissatisfaction and rebellion, Cromwell sent his players hoping to counter opposition to his ecclesiastical policies. Yet plays like Bale's King Johan and Thre Lawes with their vituperous blasphemy, caustic anti-monasticism, and shocking liturgical parody, were inappropriate and could easily be counter-productive. ${ }^{15}$ What was needed was an appeal to the genuine religious impulse, evident among regulars and laymen alike, that lay behind resistence to these suppressions. And Bale's appeal to Scripture could easily be buttressed by gentle reminders that resistence was treason and would be severely punished, as the recent mass executions of rebels had shown. Although Cromwell could ill-afford a calamitous reception, let alone risk another disastrous year of armed uprising, at the same time he could not back down from his commitment to the evangelical reform to which he had already set his hand. For these reasons, the players he sent to 
Thetford and other monasteries or into the troubled areas of the North had to breathe the sweet odor of sincerity into the atmosphere of suspicion with which regulars and conservatives would doubtless receive his messengers.

Thetford was an obvious target for Cromwell's dramatic propaganda. Founded by the Bigod family in the early twelfth century and continuing under the patronage of the earls and later the duke of Norfolk this Cluniac priory was one of the wealthier houses in England, valued at over 400 pounds at the time of its suppression in $1540 .{ }^{16}$ It was a popular venue for drama, welcoming touring companies under the patronage of various nobles almost yearly from 1497 up to its suppression. There is also evidence suggesting that members of the monastery assisted these players by acting in their plays or aiding in their production. For example, in 1529/30 the players of the duke of Norfolk performed "cum auxilio conventus" as did the king's players in $1532 / 33$. Generally no more than two patronized troupes of actors appear in any one year, but in $1537 / 38$ payment was made to four travelling troupes appearing under royal or noble patronage, among them those of the king and Cromwell. ${ }^{17}$ Evidence from Bale's trilogy gives ample support for the view it was these three plays which Cromwell's men staged during their visit to Thetford in 1537/38, and that the monks themselves participated or were expected to participate in the performance. Furthermore, the trilogy's relatively soft appeal, coupled with the absence of contemporary iconoclastic references with which Bale's other known plays were updated as the reformation progressed, suggests that it was an ideal entertainment for northern audiences like those in Shrewsbury Abbey and Leicester who lacked the stomach for the more strident Protestantism of either King Johan or Thre Lawes. ${ }^{18}$

Turning to the trilogy itself, we find three works of unequal length. The chefe promyses of god occupies nearly 1000 lines while each of the other two plays is less than half as long. Together they could have been performed in under two hours. They all derive from Scripture and adhere closely to their biblical sources. ${ }^{19}$

In the opening prologue of the first play, The chefe promyses of god, Baleus Prolocutor invites his audience to see God's hand in contemporary events:

If profyght maye growe, most Christen audyence,

By knowlege of thynges whych are but transytorye

And here for a tyme, of moch more congruence

Advauntage myght sprynge by the serche of causes heavenlye,

As those matters are that the Gospell specyfye ... (II.1-5) 


\section{8 / Renaissance and Reformation}

God's guiding action, revealed in Scripture, provides the mainspring for historical truth. From Adam's first disobedience through Isaiah's promises, God's relationship with man is seen in the history of sin, its punishment, and the opportunity for redemption. The chefe promyses of god summarizes this history from the expulsion from Eden to the coming of John the Baptist with continual foreshadowing of contemporary events. Bale relies heavily on his scriptural sources in this tour through the Old Testament and concludes with his own promise that "more of thys matter conclude herafter we shall" (I. 982) which leads into the second play of the series. Each of the six acts contains an example of man's turning away from God, his punishment, and a further instance of Divine mercy. And each closes with a sung Latin antiphon taken from vespers in the Advent liturgy - one of the Great O's, "prosequetur chorus cum organis." 20 The invitation Bale extends to his audience and the expectation that it was able and willing to sing these Advent antiphons in Latin to the accompaniment of an organ strongly suggests that a monastic setting during the Christmas season was part of his original staging.

The play is rich in allusions stemming from Bale's intention to provide a Biblical context for current events as he stated in the preface. One specific allusion can, however, provide evidence helpful in dating The chefe promyses of god to sometime after July 1536. Further internal evidence in the other two plays ties them to sometime following the general insurrection in the North and Bale's imprisonment. In act 5 Bale draws on the typographical association of Henry VIII with Israel's King David found frequently in the works of English reformers and royal pageant makers alike. ${ }^{21} \mathrm{He}$ highlights two features of David's reign which point directly to events between July 1536 and Bale's own imprisonment a few months later. Supported by his developing view that biblical events were prophetic as well as historical, Bale welds a link between Henry VIII and David which not only furthers his typological view of history but prepares his audience for the later identification of Tudor clergy with the Pharysees, and Satan as a regular. ${ }^{22}$ David is rebuked by God for his sexual sins with Bathsheba: "Of late days thu has mysused Bersabe ... (I. 606), and this sin has "defyelde" the otherwise godly king. (I. 608) The punishment is death, not for David, but for his illegitimate son:

Thu shalt not dye, David, for thys inyquyte

For thy repentaunce: but thy sonne by Bersabe

Shall dye for as moch as my name is blasphemed

Among my enemyes and thu the worse estemed. (II.617-20) 
David's other sin merits still further punishment: a "pestylence most vyle" (I. 632).

On 22 July 1536, Henry VIII's sole (and illegitimate) son Henry Fitzroy died, a fact the monks of Thetford would well remember as the young duke had been buried in their church. ${ }^{23}$ Born from the king's widely known liaison with Elizabeth Blount and created duke of Richmond in the absence of a legitimate male heir, Henry Fitzroy was a flagrant example of royal immorality, and neither Bale nor many other reformers could tolerate such flouting of God's edicts. Shortly after the duke's death, a virulent plague broke out in London, Oxford and elsewhere so that Lady Lisle's servant wrote "they die daily in the streets" and Oxford scholars fled to the countryside. ${ }^{24}$

The chefe promises's final scene with John the Baptist and its closing line of, "more of thys matter conclude herafter we shall" (I. 982) lead directly to the second play of the trilogy, Johan Baptystes preachynge. Having established the 'causes heavenlye' of man's present condition and the ongoing, even contemporary action of God in history, Bale turns to his major themethe resumption of true religion among the people of God. Using historical stereotypes, Bale casts the Baptist as a priest/preacher who anachronistically receives the confession of three representative laymen and absolves each as they turn to embrace his new message. His opponents are Sadducaeus and Pharisaeus, who proudly resist the Christian invitation to repent humbly and receive the message of salvation by faith in Christ. In the prologue, Bale had emphasized the meekness and humility of true Christians (and indeed of Christ himself):

Ye shall se Christ here submyt hymselfe to Baptym Of Johan hys servaunt, in most meke humble wyse, In poornesse of sprete that we shuld folowe hym (II 29-31)

in opposition to the "frowarde sectes [who] contynuallye rebell." (I. 28) Rebellion and pride, humility and godliness form the paired foci around which the play's message revolves.

As the play begins, John the Baptist enters preaching to Turba Vulgaris, Publicanus, and Miles Armatus. He urges them to 'flee mennys tradycyons' and instead 'Gods hygh lawes fulfill.' (I. 67) This is set out clearly in the play when John warns Pharisaeus and Sadducaeus of the coming punishment due those who wilfully turn away from God's word: 
Neyther your good workes, nor merytes of your fathers, Your fastynges, longe prayers with other holy behavers Shall yow afore God be able to justyfye ... (II. 265-67)

In an explanation of the charges against him written around the same time as this play, Bale explains that despite the lack of divine commandment for them, such traditions can be 'lawdable' - yet the office of preaching, for which there exists an irrefutable injunction, was neglected in favor of these 'constytucyons of menne.' He develops this further by saying that he never despised 'ceremonye of ye churche' but spoke against those curates who permit such things to be 'superstycyoslye takyn in ye peple for want of good techyng. ${ }^{25}$ Bale sets up the opposition, conventional in Protestant polemics between Catholic traditions devised by men and the obligations imposed by God. He will later speak more plainly, and include among those traditions the various monastic rules against which Cromwell was then proceeding.

When it comes time for Miles Armatus to submit to John for his baptism, Bale departs his biblical source in a scene depicting an idealized version of confession (which significantly partakes of none of the parody Bale levels at auricular confession in King Johan). ${ }^{26}$

John warns the knight

The offyce ye have for the publyque unyte

Mynde to exercyse to the landes tranquyltye.

Ye maye thus please God in doyng your feate ryght well. (II. 179-181, my italics), and further,

For the publique peace Gods lawe doth yow permyt

Stronge weapon to weare, but in no case to abuse it. (II. 183-83)

By invoking the fealty due to God in serving the 'landes tranquyllyte' Bale has John condemn those knights who, having taken up arms against their king in the recent conservative risings, sinned against God as well as their rightful lord.

But Bale reserves his strongest criticism for the clergy, seen in the Pharisaeus and Sadducaeus. They are referred to throughout as crafty dissemblers, wealthy and proud (which vices figure prominently in the Gospel) who conspire against John and his 'newe lernynge'. John warns them that their opposition to the Gospel involves them in the most dangerous sort of sin for it cannot be forgiven as the product of ignorance. 
I saye thys to unto yow, your observacyons are carnall, Outward workes ye have but in sprete nothynge at all ...

Synners offendynge of weakenesse, doubt or ignoraunce, Of pytie God pardoneth; but were he fyndeth resystence Agaynst the playne truthe, there wyll he ponnysh most ... (II. 237-8, 241-43)

Mirroring the machinations that had lately led to Bale's imprisonment for preaching the Protestant line, Sadducaeus promises that 'wyth a lytle helpe of an heretyke [John] wyll smell.' (I. 298) The audience is thus invited to identify the 'newe lernynge' 27 preached by persecuted reformers with the 'news' of the persecuted Baptist. Here Bale issues his broadest political challenge: those who wilfully resist the Gospel message preached by John are the forefathers of those who persecute his descendents.

The link between heresy and sedition is overturned in this analogy. Those who suppress what they call heresy are merely feigning concern for the realm's security. In a heavily ironic speech, Sadducaeus warns that

If we do not se for thys gere a dyreccyon,

This fellawe is lyke to make an insurreccyon;

For to hys [i.e. John's] newe lernynge an infynyte cumpanye

Of worldlye rascalles come hyther suspycyouslye. (II. 314-17)

All knew, of course, that it was not the preachers of the new learning but the champions of tradition who had threatened the realm's security in the recent insurrections: treason was, in fact, more dangerous than the Protestant message. ${ }^{28}$

The opposition of the haughty, scheming Pharisee, who resists John's call to the office of preaching which constitutes the essence of the priestly call, and lowly Jesus submitting himself to God's law lies at the heart of the message to regulars. Bale's Christ teaches humble obedience:

Ye worldlye people, lerne gentylnesse of me (I. 366)

Lete thys example be grafted first in your wytt,

How I for baptyme to Johan my selfe submytt. (II. 371-2)

and finally,

[I come] From my mothers house ...

To obey and serve with most due reverence (II. 379-80) 


\section{2 / Renaissance and Reformation}

Christ refers to himself as the 'great graunde captayne' (I. 400) of the people and baptism as the 'lyverye token' of the faithful (I. 413), imagery aimed as much at monastic dress as at the rebels who marched under the banner of Christ's Five Wounds. The livery of Christians lay not in cowls or noblemen's colours, nor in taking up arms against Gospel preachers but, under the token of baptism, in submitting themselves in all humility to those, like Cromwell and the king, who favor a sundering of 'mennes tradycyons' (II. 466-7) and a return to true religion. Warnings are added that on the day of judgement, such traditions will be unjustifiable without the inward conversion whose absence was clearly testified by resistance to the new learning's solafideism. Bale reiterates his theme in the closing monologue, directed specifically against monastic founders, monastic practices and men who now defend them:

The waye that Johan taught was not to weare harde clothynge,

To saye longe prayers, nor to wandre in the desart, ...

Hys mynde was that faythe shuld puryfye the hart.

My ways, sayth the Lorde, with mennys ways have no part. (II. 472-76)

Give eare unto Christ, let mennys vayne fantasyes go,

As the father bad by hys most hygh commaundement

Heare neyther Frances, Benedyct nor Bruno,

Albert nor Domynyck, for they newe rulers invent. (II. 486-89)

The word of God becomes the focus of Bale's short sequel The temptacyon of our lorde. In his prologue, he urges those who have a true vocation to accept the Spirit as their guide and Jesus as their model. But Bale must interpret the Gospel narrative of Jesus's life for his audience, lest they find in it support for practices now under censure. To the traditional view that mortification of the flesh was a remedy for temptation, Bale urges, 'For the assaultes of Sathan lerne here the remedye; / Take the worde of God, lete that be your defence.' (II. 29-30) And further, he has Jesus warn the audience,

Thynke, not me to fast bycause I wolde yow to fast,

For than ye thynke wronge and have vayne judgement.

But of my fastynge thynke rather thys my cast:

Sathan to provoke to worke hys cursed intent, And to teache yow wayes hys myschefes to prevent

By the worde of God, whych must be your defence

Rather than fastynges, to withstande hys vyolence. (II. 43-49, my italics) 
During the three temptations of Jesus, Satan is met by Scripture rather than works (II. 138ff, 208ff,' $318 \mathrm{ff}$ ) and complains, 'Nothynge can I laye but ever ye avoyde me / By the worde of God.' (II. 285-6)

Using terminology familiar to all regulars, Bale presents Christ's sojourn in the desert and his subsequent preaching as the proper 'offyce' (II. 9, 143) and likens the persecutions he suffered during his desert sojourn to those experienced by all 'whom Christ doth call.' (II. 15-20, 28) Having rejected the rule of Francis, Benedict and Bruno in the closing scene of the previous play as well as in his own apostasy, Bale offers a Protestant alternative:

Gods worde is a rule for all that man shuld do And out of that rule no creature ought to go. (II. 151-52)

The rule of the Gospel is the proper regula for Christians, and those religious who scoff at the thought of life outside the cloister are told that ascetic practices are nothing compared with the sufferings inflicted on true men of God. ${ }^{29}$

To illustrate his belief that monastic orders and Scripture are not compatible, Bale presents Satan 'simulata religione Christum aggreditur' 'semynge relygyouse, devoute and sad in my geare' (I. 75), declaring

Scriptures I knowe non for I am but an hermyte, I.

I maye saye to yow it is no part of our stody;

We relygyouse men lyve all in contemplacyon

Scriptures to stodye is not our occupacyon;

It longeth to doctours. (II. 157-61)

Notwithstanding this admission of willed ignorance in Scriptural matters, Satan's assaults on Jesus hinge on Scriptural interpretations-interpretations easily refuted because of their very selectivity. ${ }^{30}$ Jesus admonishes him;

In no wyse ye ought the scriptures to deprave

But as they lye whole so ought ye them to have. (II. 215-16)

Bale suggests that it is out of spiritual pride that men support monastic orders, pride which tempts God. When Satan asks just what does it mean to tempt God, Jesus replies:

To take of hys worde an outwarde experyment

Of an ydle brayne, whych God neyther thought nor ment.

When asked what persons do this, Jesus replies: 
All soch as forsake anye grace or remedye Appoynted of God for their owne polycye. As they that do thynke that God shuld fyll their bellye Without their labours, whan hys lawes are contrarye;

and

Those also tempt God that vowe presumptuouslye,

Not havynge hys gyft to kepe their contynencye,

With so manye els as folowe their good intentes,

Not grounded on God, nor yet on hys commaundements; (II 255-64)

Just as Jesus resisted turning stones in to bread out of faith that God would provide for his needs, Bale is asking the regulators to anticipate God's providence once they are out of the cloister. In a restrained polemical flourish, he includes references to monastic idleness and incontinency, but the mildness with which he offers these assessments is significant when compared with the catalogue of monastic abuses presented elsewhere in his writings. This degree of tonal control, essential for effective propaganda, further underscores the suggested application for which these plays were intended.

Bale closes his play with a challenge to the regulars: there is no life as rigorous as that to which the Gospel calls us. Satan is to be resisted

Not with your fastynges-Christ never taught ye so -

But with a stronge fayth withstande hys false suggestyon

And with the scriptures upon hym ever go. (II. 413-15)

In sum, we can see that this trilogy was written sometime after the death of Henry Fitzroy in July 1536 and the end of the northern risings the following winter (with particular reference to Advent.) That Bale's trilogy was addressed primarily to a clerical audience, for whom the Reformation posed the most radical challenge, is clear from its content alone but is further borne out by the stage directions in the first play calling for choral singing of Latin antiphons with organ accompaniment and in later presentation of Christ's message in terms deliberately echoing monastic language and criticizing specific monastic practices. Bale speaks of Christ's 'office' (Johan Baptystes preachynge I. 425, The temptacyon of our lorde, I. 9) the 'rule' of God's word (Johan Baptystes preachynge II. 151-2), and frequently emphasises the monastic virtues of obedience, patience, and humility. (e.g. obedience, Johan Baptystes preachynge I. 380; humility Johan Baptystes preachynge II. 30, $366,369,461$, 464; patience, The temptacyon of our lorde I. 33.) His reformed 
theology, presented in the simplified terms essential for propaganda, is here restrained and decorous, appealing both to the desire for conventionally expressed religious discipline (which Bale presented as the rule of God's word) as well as to the Protestant notion that monastic orders were, in fact, Satan's subtle strategems lacking scriptural support and therefore offensive to true religion. In place of monastic observance, Bale offers the office of preaching, for which he held up John and Jesus as examples.

Ultimately, Cromwell's efforts failed to contain the events they triggered. Despite his far-flung network of agents and supporters, Cromwell himself proved incapable of defusing the largely court-centered opposition to evangelical reforms, opposition which sent him to the block in 1540 and many of his propagandists into exile. But the message his dramatists brought to the fringes of the troubled North in 1537/38 and elsewhere may have had some impact. There was no repeat of the Pilgrimage of Grace when the big abbeys came down, and despite their ad hoc nature, the plays gained new relevance following the imposition of the 6 Articles in 1539 and other legislation which reaffirmed many practices repugnant to radical reformers. It was for this reason that Bale took these works with him into exile, and saw to their publication and later production.

\section{University of Otago}

\section{Notes}

* I would like to thank Professor Alistair Fox for his helpful criticism during the writing of this paper.

1. For Cromwell's propaganda campaign, see G.R. Elton, Policy and Police: The Enforcement of the Reformation in the Age of Thomas Cromwell, (Cambridge, 1972), pp. 171-216; J. Block, "Thomas Cromwell's Patronage of Preaching," Sixteenth Century Journal VIII (April, 1977), pp. 37-50. For an introduction to political drama in this period, see D. Bevington, Tudor Drama and Politics: a Critical Approach to Topical Meaning (Cambridge, Mass. 1968); S Anglo, Spectacle, Pageantry, and Early Tudor Policy, (Oxford, 1969); A. Fox, Politics and Literature in the Reigns of Henry VII and Henry VIII (Oxford, 1989); and R. Blackburn, Biblical Drama under the Tudors (The Hague and Paris, 1971). The author is currently working on a detailed analysis of the use of drama during the Henrician Reformation, including the Cromwell/Bale partnership.

2. For the most complete compilation of data concerning drama in England until 1558, see I. Lancashire, Dramatic Texts and Records of Great Britain: a Chronological Survey to 1558 (Toronto, 1984), esp. Appendix I, pp. 349-408 for dramatic companies and their patrons.

3. For Bale's bibliography and biography, see W.T. Davies, "A Bibliography of John Bale," Oxford Bibliographical Society, Proceedings and Papers V, pt.iv 1939 (1940), pp. 201-279; H. McCusker, John Bale, Dramatist and Antiquary 1942 (rpr. Freeport, 


\section{6 / Renaissance and Reformation}

1971); J.W. Harris, John Bale: a Study in Minor Literature of the Reformation (Urbana, 1940); to some extent these have all been replaced by L. Fairfield, John Bale: Mythmaker for the English Reformation (West Lafayette, 1976); for a critical introduction to Bale's plays, see T. Blatt, The Plays of John Bale (Copenhagen, 1968). Bale's plays have received an excellent modern edition by P. Happe', Complete Plays of John Bale, 2 vols., (Cambridge, 1985-6). All references to the plays in this article cite line numbers from this edition; for the demise of cycle plays, see G. Wickham, Early English Stage, London, 1980, I, pp. 112-123.

4. See Fairfield, Mythmaker, chaps. 3 and 4.

5. Cromwell had come to Bale's aid before, which Bale credited to his playwriting ability. But as Bale held no position other than that of a stipendiary curate in Suffolk until 1537, Cromwell's patronage must have been very active. For various accounts of Bale's troubles until Cromwell began using his services in early 1537, see A.G. Dickens, Lollards and Protestants in the Diocese of York (Oxford 1959) pp. 144-5; Fairfield, John Bale: Mythmaker, pp. 36-49; and McCusker, John Bale, Dramatist pp. 6-13 who prints Bale's own answer to the charges against him as well as letters from Bale and Leland to Cromwell from around the same time. The calendered abstracts are unreliable, c.f. Letters and Papers, Foreign and Domestic, of the Reign of Henry VIII 1509-1547, eds. J. Brewer et al. 21 vols plus Addenda, Vol. (London 1867-1920), henceforth $L P$ followed by volume, part, and document number) XI, 1111 (which should be re-dated to early 1537) and XII, i, 230.

6. Harris, John Bale, pp. 65-6; LP XIV, ii, p. 337; Lancashire, Dramatic Texts and Records, p. 380; J E Cox (ed.) Miscellaneous Writings and Letters of Thomas Cranmer Parker Society (Cambridge, 1846) p. 388; Happe' Complete plays I, pp. 4-7; John Bale, The Vocacyon of John Bale, Harleian Miscellany VI (London, 1810) p. 450; Records of Early English Drama: Cambridge, ed. Alan Nelson (Toronto, 1989), i, pp. 112, 114, 119)

7. See Happe', Complete Plays, I, p. 6-7.

8. The cult was officially suppressed on 16 November, 1538 and the saint's name was to be effaced from all service books. Tudor Royal Proclamations, eds. P. Hughes and J. Larkin, Vol. I (New Haven and London 1964) no. 186. The shrine had begun to be dismantled by Richard Pollard and others on 7 September, the night before Bale's performance. $L P$ XIII, ii, 302, 303, 417. The king and most of the court were present.

9. See Historical Manuscript Commission, 15th Report, pt. 10 (1899), p. 34 for Shrewsbury; Lancashire, Dramatic Texts and Records \#833 for Leicester.

10. See McCusker, John Bale, pp. 5 ff.

11. For introductory remarks on the Pilgrimage of Grace, see Guy, Tudor England (Oxford, 1989) pp. 149, 152; D. Knowles, The Religious Orders in England, v.III (Oxford, 1959) pp. 320-335; and the useful but dated M. and R. Dodds The Pilgrimage of Grace, 1536-37 and the Exeter Conspiracy 1538 (2 vols., Cambridge, 1915); for political songs sung at Thetford see $L P$ XII, i, 424 and against Cromwell, $L P$ XII, i, 318; for uprisings in Wales, see $L P$ XII, i, 1148, 1271, 1272; for the offending May Day game in Suffolk, see $L P$ XII, i, 1212, 1284.

12. $L P \mathrm{XII}, \mathrm{i}, 808 ; L P \mathrm{XII}, \mathrm{ii}, 800$. 
13. Dodds, Pilgrimage of Grace, ii, p. 155; G. Cook, Letters to Cromwell and Others on the Suppression of the Monasteries (London, 1965), pp. 129, 137; LP XII, ii, 190; Lewes priory followed in voluntary submission to the king in November 1537, LP XII, ii, 1101 .

14. LP XII, ii, 1314, 1101, 1311(30).

15. Just to whom these plays would be acceptable in the late 1530's is a good question. Bale seems to have put on King Johan before Cranmer but after the appearance of the 6 Articles in 1539, it would take a brave actor indeed to present its lines.

16. W. Dugdale Monasticon Anglicanum, eds. Calley and Ellis, 6 vols. (London, 1817 1830), v (1825), pp. $141 \mathrm{ff}$.

17. R. Beadle, "Plays and Playing at Thetford and Nearby 1498-1540", Theatre Notebook 32 (1978), pp. 4-11; D. Galloway and J. Wasson, eds., Records of Plays and Players in Norfolk and Suffolk 1330-1642, Malone Society Collections XI (1980), pp. 104-115. The yearly accounts were kept from 24 June to 23 June. For $1537 / 38$, the entries for drama are spread across 6 pages. From their grouping one may only hazard the guess that Cromwell's men were not accompanied by any of the other troupes to appear that year.

18. For evidence that Bale updated King Johan and Thre Lawes, see Happe' Complete Plays I, pp. 8-11; the added list of relics in these two plays seems to have rendered them particularly appropriate for Cromwell's campaign against images in 1538; King Johan was updated at least as late as 31 August 1538 because of the reference to John Shorne's boot (I. 1225); see $L P$ 13, ii, 235; reference to St. Uncumber (I. 532) suggests that Thre Lawes was updated as late as $16 \mathrm{July}, 1538$ when this shrine came down in London, LP XIII, i, 1393. Bale added to these plays while in exile, but his alterations mainly reflect the change in monarchs. See e.g. King Johan I. 2671, Thre Lawes II. 2040, 1575-76, etc.

19. For the series as a trilogy, see Happe' Complete Plays I, p. 12-13.

20. E.S. Miller, "The Antiphons in Bale's Cycle of Christ," Studies in Philology 48 (1951) pp. 629-38; Happe' Complete Plays I, pp.23 ff.

21. See S. Anglo, Spectacle, Pageantry and Early Tudor Policy, p. 214; David was one of Henry VIII's favorite biblical characters. Tyndale too made much use of David's adultery to show what punishment results from flouting God's laws, even by pious kings, in his 'Exposition of Matthew' V, VI, VII, (ed.) Duffield, The Works of William Tyndale, Courtenay Library of Reformation Classics, I (Appleford, 1964) p. 228.

22. Throughout these three plays, Bale is largely faithful to the scriptural accounts. His belief in Scripture's inerrancy and in the precision with which it could be applied to the present is seen here in its earliest phase. Later, Bale relies heavily on Scripture to formulate his understanding of the historical ages of the true Church-an understanding shared by the Protestant martyrologist John Foxe.

23. Wriothesley's Chronicle, ed. W. Hamilton, Camden Society (1875), i, pp. 53-54.

24. LP XI, 162, 310, 405, 501, 970, 1181.

25. McCusker, John Bale, pp. 10-11.

26. E.S. Miller, “The Roman Rite in Bale's King John," Publications of the Modern Language Association, 49 (1959) pp. 802-22; Other literary priests used canonical or 
sacramental rites, particularly the confessional, as a basis for parody. See J. Wilson, "Skelton's Ware the Hauke and the 'Circumstances' of Sin" Medium Aevum LVII (1989) pp. 243-57.

27. The theme of newness illustrates the reformers' use of Gospel history to illuminate contemporary events (cf. II. 17, 207-8, 211, 282, 275 etc.) John's news, which was indeed new, becomes in Bale the 'newe lernyng'-that is, a return to what reformers called Biblical Christianity.

28. Again, in his answer to the articles against him in 1536/7 Bale responds that he was working in the king's cause, upholding the 10 Articles; McCusker, John Bale, pp. 6-11.

29. Using Christ (and the recent Protestant martyrs) as his models, Bale stresses the persecutions in store for those who follow Christ: e.g. "If ye folowe Christ, with hym ye must be beate" The temptacyon of our lorde, I. 28. Here he echoes Tyndale's call for baptism in tribulation, The Obedie[n]ce of a Christen Man (Antwerp, 1528) fos, vi-x.

30. English Bibles remained unavailable in England until Cromwell's injunctions of September 1538 although it was not until sometime in 1539 that they were available in any quantity. For a short account of the Bible in English, see S.L. Greenslade, 'English Versions of the Bible 1525-1611' Cambridge history of the Bible, 3 vols., (Cambridge, 1963-70) iii, pp. 149-53. 